\title{
PENGARUH KEPRIBADIAN (EKSTROVERT VS INTROVERT) TERHADAP WATER FOOTPRINT SISWA SEKOLAH MENENGAH ATAS DI JAKARTA
}

\author{
Effect of personality (Extraversion vs Introversion) on Ecological \\ Footprint of High School Student in Jakarta.
}

I Made Putrawan, Diana Vivanti Sigit, Angela Maria Pendidikan Biologi Fakultas MIPA Universitas Negeri Jakarta

Email: putrawan.imade@yahoo.com

\begin{abstract}
The increasing of economic growth evoked the prosperity of its citizen which subsequently would lead to the consumption behaviors of such population for goods andservices. Ecological Footprint is a individual or population as well as the services needed to assimilate west in term of land. Social factors, such as personality, is known as a crucial factor that cause the consumption pattern of individuals is vary considerably. This research was aimed to determine the effect of personality on Ecological Footprint of students at senior high school in Jakarta. Measuring of Ecological Footprint is concentrated on water using at home and school. The activities of water using focused on urinating, defecating, face washing, taking a bath, hand washing, and ritual ablution before Moslem prayers. Water Footprint was calculated from 54 students enrolled in SMAN 107 which are selected acording to simple random sampling, Cakung Jakarta Timur This study was conducted from January to February 2016. The finding indicated that there was no significantly difference between extraversion and intraversion based on their total Water Footprint value.
\end{abstract}

\section{Keyword : Ecological footprint, water footprint, extraversion, intraversion, high school students in Jakarta}

\section{PENDAHULUAN}

Air adalah salah satu produk sumber daya alam yang dikonsumsi secara rutin oleh individu. Produk yang dikonsumsi oleh masyarakat membutuhkan sumber daya alam pada proses produksinya. Artinya, mengkonsumsi produk (dalam hal ini air) sama dengan mengkonsumsi sumber daya alam. Pola konsumsi air yang meningkat terutama di wilayah perkotaan memunculkan sebuah pertanyaan apakah sumber daya yang dimiliki mencukupi kebutuhan akan air seluruh populasi manusia atau tidak. Jumlah air yang diproduksi memerlukan lahan untuk menopang kebutuhan masyarakat, maka meningkatnya perilaku konsumsi di masyarakat harus diimbangi dengan ketersediaan lahan yang ada. Kehidupan yang berkelanjutan dapat dicapai dengan memastikan bahwa seluruh umat manusia hidup dengan memanfaatkan air secara wajar dan tidak berlebihan.

Perilaku individu dalam konsumsi produk kebutuhan dapat dipengaruhi oleh faktor sosial, budaya, kepribadian dan psikologi. Faktor kepribadian yang mempengaruhi pola 
konsumsi antara lain ekstrovert dan introvert. Kepribadian ekstrovert memiliki kecenderungan memiliki pola konsumsi yang lebih tinggi dibandingkan dengan kepribadian introvert. Diduga kepribadian ekstrovert yang memiliki kecenderungan senang bersosialisasi atau bergaul, menggunakan air dalam jumlah yang lebih banyak dibandingkan dengan seseorang yang berkepribadian introvert yang cenderung lebih senang untuk menyendiri.

Sangat penting apabila setiap individu dengan kepribadian apapun dapat mengetahui ketersediaan air yang dapat menopang kebutuhannya. Keseimbanagan antara kebutuhan air dan jumlah air yang tersedia sangat penting untuk dipahami.Dalam mengatasi masalah tersebut, beberapa indikator dan konsep telah diciptakan untuk mengukur jumlah air yang digunakan yaitu Water Footprint. Water Footprint didefinisikan sebagai total volume air tawar yang dikonsumsi oleh individu, bisnis atau negara yang dibutuhkan untuk menjaga keberlanjutan suatu populasi. Penelitian mengenai Water Footprint pada siswa menengah atas belum banyak dilakukan. Siswa sebagai bagian dari masyarakat juga berpengaruh pada pola konsumsi sumber daya alam. Siswa harus mampu memahami cara penggunaan air secara efisien, memngingat ketersediaan air bersih yang terbatas. Oleh karena latar belakang inilah penelitian mengenai pengaruh kepribadian ekstrovert dan introvert terhadap Water Footprint siswa Sekolah Menengah Atas dilakukan.

\section{METODE}

Penelitian pengaruh kepribadian (ekstrovert vs introvert) terhadap Water Footprint siswa sekolah menengah atas di Jakarta menggunakan metode expost-facto. Penelitian ini memiliki dua variabel, yaitu kepribadian sebagai variabel bebas (X) dan Water Footprint siswa SMAN 107 Jakarta Timur sebagai variabel terikat (Y). Penelitian pendahuluan juga dilakukan guna mendapatkan gambaran penggunaan air siswa dalam satu hari. Penelitian dilaksanakan di SMAN 107, Cakung, Jakarta Timur, DKI Jakarta pada bulan Januari 2016 sampai Februari 2016. Populasi dalam penelitian ini adalah seluruh siswa SMA di DKI Jakarta. Pemilihan sampel dan populasi dengan menggunakan teknik pemilihan sampel bertingkat (multistage sampling). Tingkat pertama sampel dipilih secara purposive sampling yaitu memilih Jakarta Timur sebagai sampel dari populasi DKI Jakarta.Tingkat kedua dengan memilih SMA di kawasan Jakarta Timur. Dari seluruh sekolah yang ada dipilih SMAN 107 Jakarta Timur dipilih secara cluster random sampling sebagai sampel penelitian.

Pada tingkat ketiga menjadikan siswa kelas XI sebagai sampel penelitian. Hal ini karena kelas tersebut telah memenuhi kegiatan belajar mengajar selama satu tahun. Persyaratan ini merupakan penerapan dari analisis Water Footprint yang menghitung pola konsumsi individu pada tahun tertentu. Pada tahap keempat pemilihan sampel dari populasi dilakukan dengan teknik cluster random sampling. Sampel dari kelompok kelas (cluster) dipilih dengan mengundi kelas yang akan jadi sampel penelitian. Tahap kelima pemilihan sampel dari tiap kelas yang telah terpilih secara cluster random sampling. Responden dalam penelitian ini adalah terdiri dari siswa kelas XI yang berjumlah 108 siswa. Siswa yang telah mengisi kuesioner kepribadian dibagi menjadi dua berdasarkan skor yang tertinggi (upper group) dan siswa dengan skor yang lebih rendah (lower group). Resonden yang berjumlah 108 siswa diambil 27\% diperoleh 29 responden yang telah diranking terlebih dahulu sehingga terbagi atas upper group (kelompok dengan skor lebih tinggi) dan lower group 
(kelompok dengan skor lebih rendah). Responden yang memiliki skor lebih tinggi yaitu responden yang memiliki kepribadian ekstrovert. Responden yang memiliki skor lebih rendah yaitu responden yang memiliki kepribadian introvert. Siswa dengan kepribadian ekstrovert berjumlah 29 siswa dan siswa berkepribadian introvert 29 siswa. Untuk menentukkan jumlah sampel, dilakukan simple random sampling dan menyisakan 27 sampel baik sampel yang berasal dari kepribadian ekstrovert dan introvert. Jumlah total sampel yang diteliti sebanyak 54 siswa.

\section{TEMPAT DAN WAKTU PENELITIAN}

Penelitian ini dilaksanakan di SMAN 107, Cakung, Jakarta Timur, DKI Jakarta pada bulan Januari 2016 sampai Februari 2016.

\section{SAMPEL PENELITIAN}

Responden dalam penelitian ini adalah terdiri dari siswa kelas XI yang berjumlah 108 siswa. Siswa yang telah mengisi kuesioner kepribadian dibagi menjadi dua berdasarkan skor yang tertinggi (upper group) dan siswa dengan skor yang lebih rendah (lower group). Resonden yang berjumlah 108 siswa diambil 27\% diperoleh 29 responden yang telah diranking terlebih dahulu sehingga terbagi atas upper group (kelompok dengan skor lebih tinggi) dan lower group (kelompok dengan skor lebih rendah). Responden yang memiliki skor lebih tinggi yaitu responden yang memiliki kepribadian ekstrovert. Responden yang memiliki skor lebih rendah yaitu responden yang memiliki kepribadian introvert. Siswa dengan kepribadian ekstrovert berjumlah 29 siswa dan siswa berkepribadian introvert 29 siswa. Untuk menentukkan jumlah sampel, dilakukan simple random sampling dan menyisakan 27 sampel baik sampel yang berasal dari kepribadian ekstrovert dan introvert. Jumlah total sampel yang diteliti sebanyak 54 siswa.

\section{PROSEDUR ANALISIS DATA}

Prosedur analisis data didahului dengan pengambilan data kepribadian siswa yang berupa skor dan data Water Footprint siswa. Setelah mendapatkan skor kepribadian siswa dan besaran Water Footprint siswa,data distandarisasikan melalui perhitungan $\mathrm{Z}$ score dari masing-masing variabel yang diujikan. Cara pengukuran yang antara kepribadian dan Water Footprint membuat skor kepribadian siswa dan besaran Water Footprint perlu disetarakan dengan satuan yang sama

Sebelum melakukan uji hipotesis, diperlukan beberapa uji prasyarat untuk memutuskan tentang hasil uji hipotesis apa yang sesuai berdasarkan data yang diperoleh. Kedua uji prasyarat tersebut masing-masing adalah uji normalitas dan uji homogenitas. Uji normalitas pada penelitian digunakan uji Kolmogorov Smirnov. Uji normalitas digunakan untuk mengetahui apakah populasi data berdistribusi normal atau tidak. Selanjutnya dilakukan uji F. Uji F digunakan untuk mengetahui kesamaan varians. Pengujian berikutnya menggunakan uji Student's t-test indepent sample, yaitu pengujian yang digunakan untuk membandingkan rata-rata dari dua kelompok sampel. Hal ini karena kedua kelompok (siswa dengan kepribadian ekstrovert dan siswa dengan keppribadian introvert) sampel berasal dari kelompok yang tidak saling berhubungan (independen). Semua perhitungan dalam pengujian hipotesis menggunakan perangkat lunak statistik, yaitu Microsoft Excel dan SPSS (Statistical Package for Social Science) versi 17.0. 


\section{HASIL}

a. Kepribadian siswa

Data untuk variable kepribadian siswa dibagi menjadi dua yaitu, siswa berkepribadian ekstrovert dan siswa berkepribadian introvert.

1. Siswa berkepribadian ekstrovert

Penentuan kepribadian siswa adalah dengan cara memberikan skor yang diujikan melalui kuesioner politom. Hasil perhitungan skor kepribadian siswa ekstrovert adalah sebagai berikut:

Skor tertinggi yang diperoleh adalah 152 dan nilai yang terendah adalah 123 dari rentang skor 1-5. Pada Tabel 4 diuraikan rata-rata skor siswa berkepribadian ekstrovert adalah 135,5 dengan varians yang diperoleh adalah 40 dan standar deviasi sebesar 6 . Skor yang memiliki frekuensi tertinggi berada pada rentang kelas 133-137 yaitu sebanyak 13 siswa dengan frekuensi relatif sebesar $48,15 \%$. Skor yang memiliki frekuensi terendah berada pada rentang kelas 148-152 yaitu sebanyak 1 siswa dengan frekuensi relatif sebesar 3,70\% .

\begin{tabular}{|c|c|c|c|}
\hline Kepribadian & Rata-rata & Varians & Standar deviasi \\
\hline Ekstrovert & 135,5 & 40 & 6 \\
\hline
\end{tabular}

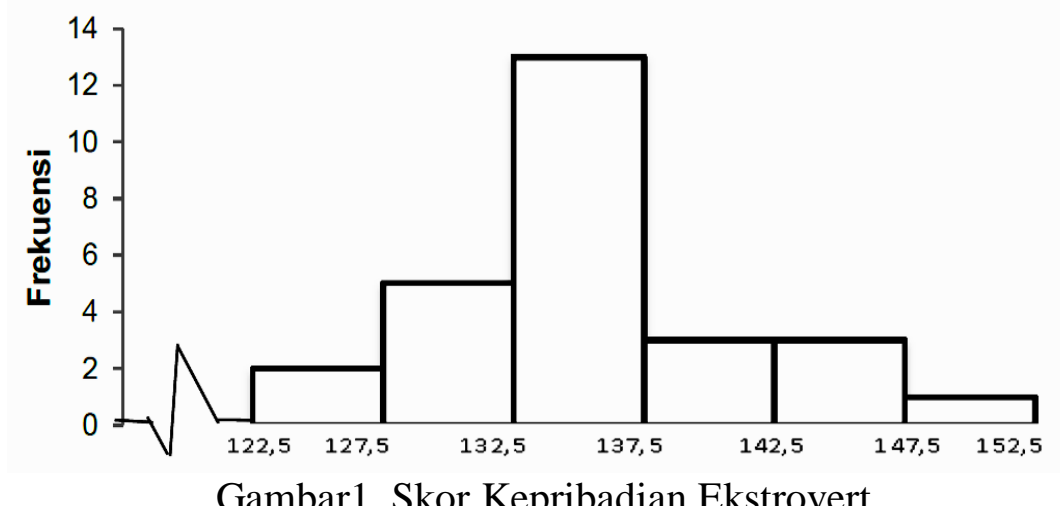

2. Siswa berkepribadian introvert

Penentuan kepribadian siswa adalah dengan cara memberikan skor yang diujikan melalui kuesioner politom. Hasil perhitungan skor kepribadian siswa introvert adalah sebagai berikut:

\begin{tabular}{|c|c|c|c|}
\hline Kepribadian & Rata-rata & Varians & Standar deviasi \\
\hline Introvert & 114,5 & 18 & 4 \\
\hline
\end{tabular}


Skor tertinggi yang diperoleh adalah 120 dan nilai yang terendah adalah 103 dari rentang skor 1-5. Pada Tabel 4 diuraikan rata-rata skor siswa berkepribadian ekstrovert adalah 114,5 dengan varians yang diperoleh adalah 18 dan standar deviasi sebesar 4. Skor yang memiliki frekuensi tertinggi berada pada rentang kelas 115-177 yaitu sebanyak 9 siswa dengan frekuensi relatif sebesar 33,3\%. Skor yang memiliki frekuensi terendah berada pada rentang kelas 103-105 yaitu sebanyak 2 siswa dengan frekuensi relatif sebesar $7,4 \%$.

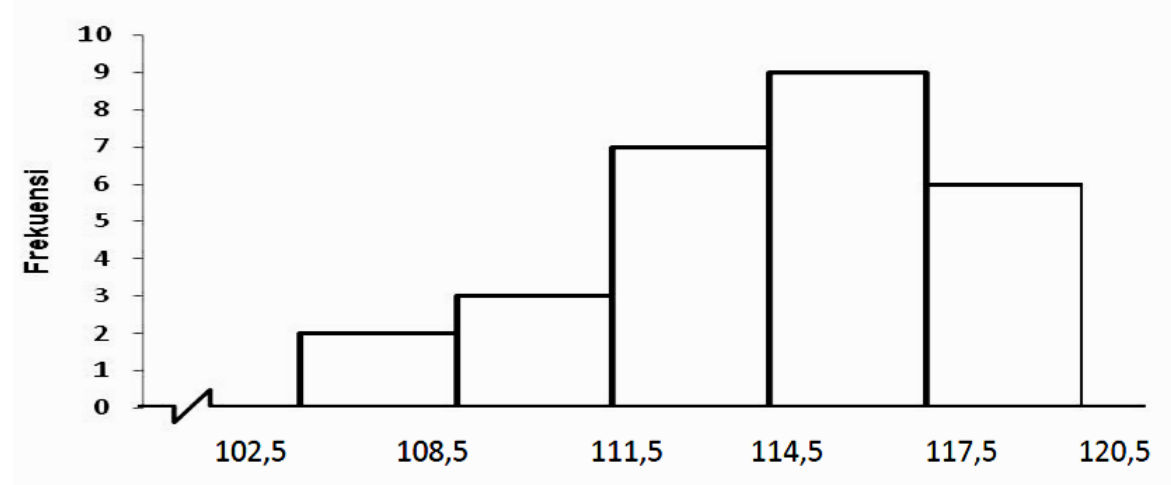

Gambar 2. Skor kepribadian Introvert

b. Water Footprint siswa

1. Hasil survey pendahuluan adalah sebagai berikut:

\begin{tabular}{|c|l|c|c|}
\hline \multirow{2}{*}{ Komponen } & \multirow{2}{*}{ Kegiatan Konsumsi } & \multicolumn{2}{|c|}{ Rata-rata konsumsi individu } \\
\cline { 3 - 4 } & & $\begin{array}{c}\text { Satuan } \\
\text { (liter) }\end{array}$ & $\begin{array}{c}\text { Satuan } \\
\text { (gallon) }\end{array}$ \\
\hline \multirow{5}{*}{ Air } & Minum & $\mathbf{1 , 5 5}$ & $\mathbf{0 , 4 1}$ \\
\cline { 2 - 4 } & Mencuci wajah & $\mathbf{1 2 , 5 0}$ & $\mathbf{3 , 3 0}$ \\
\cline { 2 - 4 } & Buang air besar & $\mathbf{1 3 , 7 0}$ & $\mathbf{3 , 6 2}$ \\
\cline { 2 - 4 } & Mencuci tangan & $\mathbf{2 9 , 7 0}$ & $\mathbf{7 , 8 5}$ \\
\cline { 2 - 4 } & Buang air kecil & $\mathbf{4 6 , 6 0}$ & $\mathbf{1 2 , 3 1}$ \\
\cline { 2 - 4 } & Wudhu & $\mathbf{5 5 , 0 0}$ & $\mathbf{1 5 , 5 3}$ \\
\hline & Mandi & $\mathbf{5 9 , 2 0}$ & \\
\hline
\end{tabular}

2. Water Footprint Seluruh Siswa

Berdasarkan hasil pengukuran total Water Footprint dari 54 siswa baik di sekolah maupun di rumah diperoleh besaran 0,3075 gHa/gallon. Water Footprint terendah sebesar $0,0022 \mathrm{gHa} /$ gallon (Lampiran 15a) dan total Water Footprint tertinggi adalah 0,0100 $\mathrm{gHa} / \mathrm{gallon}$ dengan rata-rata total Water Footprint seluruh siswa sebesar 0,0057 gHa/gallon.

3. Rata-rata Total Water Footprint Seluruh Siswa per Kegiatan 


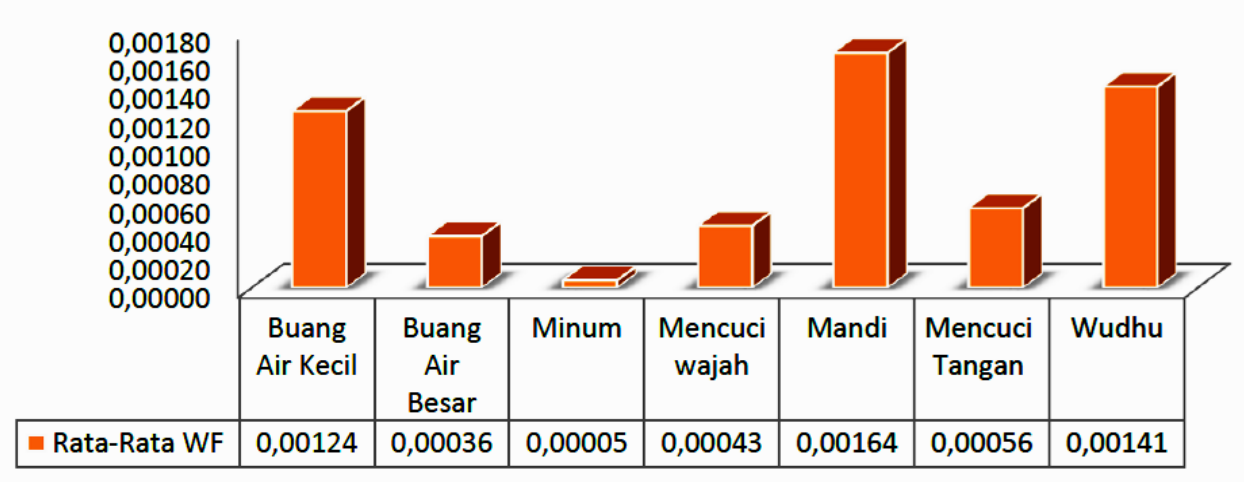

Gambar 3. Rata-rata Total Water Footprint Seluruh Siswa per Kegiatan

4. Water Footprint Kepribadian Ekstrovert dan Introvert

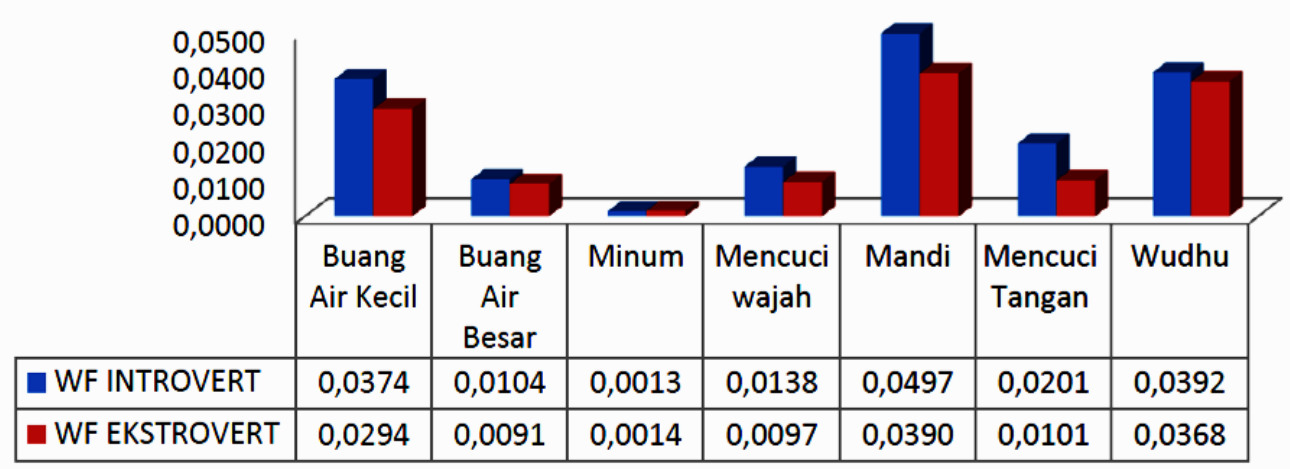

Gambar 4. Water Footprint Kepribadian Ekstrovert dan Introvert

\section{PEMBAHASAN}

Kebutuhan air setiap individu berbeda satu dengan yang lainnya. Jumlah air yang digunakan oleh individu berkaitan dengan upaya pemenuhan kebutuhan individu tersebut, sehingga Water Footprint yang dihasilkan oleh individu berbeda-beda. Berdasarkan hasil penelitian, besaran total Water Footprint siswa berbeda-beda, baik yang berkepribadian ekstrovert dan introvert. Siswa berkepribadian ekstrovert memiliki total besaran Water Footprint 0,13552 gHa/gallon (Lampiran 16), sedangkan siswa berkepribadian introvert Water Footprintnya sebesar 0,17200 gHa/gallon (Lampiran 17).

Besaran Water Footprint secara deskriptif sangat dibutuhkan untuk mengetahui seberapa besar dampak yang dihasilkan individu terhadap alam. Kegiatan konsumsi yang dihitung Water Footprintnya meliputi buang air kecil, buang air besar, minum, mencuci wajah, mandi, mencuci tangan, dan wudhu. Total Water Footprint siswa yang paling besar baik yang berkepribadian ekstrovert maupun introvert adalah pada kegiatan mandi. Total Water Footprint siswa berkepribadian introvert untuk kegiatan mandi sebesar 0,0497 gHa/gallon (Lampiran 17) sedangkan untuk Water Footprint siswa berkepribadian ekstrovert untuk kegiatan mandi adalah 0,0390 gHa/gallon (Lampiran 16). Total Water 
Footprint yang paling rendah pada kedua kepribadian ini adalah Water Footprint pada kegiatan minum. Pada kepribadian introvert sebesar 0,0013 gHa/gallon (Lampiran 17) dan untuk kepribadian ekstrovert 0,0014 gHa/gallon (Lampiran 16). Hal ini dikarenakan jumlah air yang dibutuhkan untuk mandi paling banyak dibandingkan dengan penggunaan air pada kegiatan mengkonsumsi air lainnya, sedangkan penggunaan air untuk minum memiliki jumlah penggunaan paling sedikit diantara kegiatan konsumsi lainnya. Individu harus mengetahui jumlah air yang dihabiskannya dan ketersediaan air di alam, sehingga keseimbangan antara kebutuhan dan ketersediaan air dapat selalu diperhatikan oleh individu.

Untuk menguji hipotesis penelitian, maka dilakukan uji beda antara dua kelompok siswa dengan kepribadian yang berbeda. Berdasarkan uji beda dengan perhitungan uji t, antara kepribadian ekstrovert dan introvert untuk total Water Footprint tidak terdapat perbedaan. Hasil uji t yang didapat adalah 1,37. Angka tersebut bernilai lebih kecil jika dibandingkan dengan t tabel yang bernilai 2,00 (Lampiran 25). Hal ini menunjukkan tidak terdapat perbedaan besaran Water Footprint antara siswa yang berkepribadian ekstrovert maupun introvert. Kondisi tersebut membuat peran siswa berkepribadian ekstrovert dan introvert terhadap dampak pada alam menjadi sama. Penggunaan air yang tidak berbeda ini disebabkan karena rata-rata penggunaan air pada umumnya oleh individu sama dalam kegiatannya. Misalnya, individu dengan kepribadian ekstrovert atau introvert umumnya mandi 2 kali dalam sehari, sehingga jumlah air yang digunakan untuk kegiatan ini relatif sama.

Pada sisi lain diduga terdapat faktor lain yang mempengaruhi Water Footprint siswa. Salah satunya adalah pengetahuan. Pada penelitian sebelumnya, dikatakan bahwa kontribusi pengetahuan terhadap Ecological Footprint (termasuk Water Footprint didalamnya) tergolong tinggi. Hal ini dikarenakan, pengetahuan yang dimiliki siswa dapat mengubah pola perilaku konsumsi siswa. Siswa yang memiliki pengetahuan yang tinggi cenderung tidak boros dalam hal mengkonsumsi berbagai produk kebutuhan salah satunya adalah air. Hal ini sesuai dengan pernyataan bahwa pengetahuan dapat menyebabkan terjadinya perubahan sikap manusia yang secara langsung mempengaruhi pola perilaku.

Pada penelitian lainnya dikatakan bahwa jika manusia lebih memahami bahkan lebih sadar akan lingkungan, mereka akan termotivasi untuk lebih responsif terhadap lingkungan yang menyediakan air sebagai sumber daya alam yang tersedia. Pada Gambar 6 menggambarkan hubungan pengetahuan dengan perilaku atau respon terhadap lingkungan.

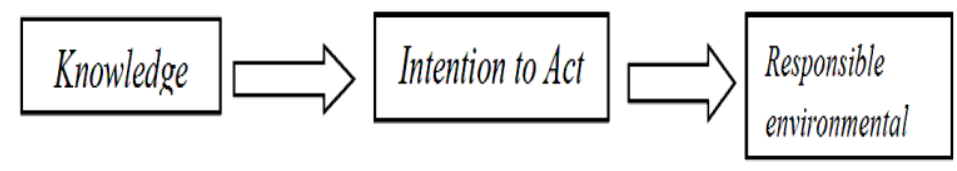

Gambar 5. Kaitan pengetahuan dengan perilaku atau respon terhadap lingkungan

Faktor lain yang diduga mempengaruhi besaran total Water Footprint siswa, misalnya latar ekonomi keluarga. Latar belakang ekonomi membentuk status sosioekonomi masyarakat yang mengalami peningkatan dalam perilaku mengkonsumsi berbagai jenis produk kebutuhan.

Jakarta sebagai kota lokasi dari SMAN 107 merupakan kota yang memiliki tingkat 
ekonomi yang paling tinggi dibandingkan dengan kota-kota lain di Indonesia. Hal tersebut membuat perilaku konsumsi menjadi lebih tinggi daripada daerah lain diluar Jakarta karena daya beli siswa akan meningkat seiring peningkatan ekonominya. Siswa dengan tingkat ekonomi orang tua yang tinggi merasa tidak cukup puas dengan hanya memenuhi kebutuhan dasar, namun juga memberi banyak pilihan tentang bagaimana cara mendapat atau memilih jenis dari kebutuhan dasar seperti memperhatikan kesehatan, kehidupan yang nyaman, dan lain-lain. Ketidakpuasan tersebut membentuk status sosio-ekonomi siswa yang mengalami peningkatan dalam perilaku mengkonsumsi berbagai jenis produk kebutuhan. Sebagai contoh konkret, seorang siswa yang memiliki latar belakang ekonomi lebih tinggi tidak cukup puas dengan air minum yang mereka bawa dari rumah. Acapkali mereka membeli minum tambahan ketika berklumpul bersama teman sejawatnya. Sebaliknya, siswa yang memiliki latar belakang ekonomi yang rendah, mereka akan cenderung berhemat dan memilih untuk cukup membawa minum dari rumah. Ilustrasi ini dapat menggambarkan penggunaan air yang berbeda jika dilihat dari sudut pandang latar belakang individu siswa.

Water Footprint atau jejak air adalah suatu gambaran atau alat ukur yang dapat dijadikan acuan untuk mengetahui seberapa banyak seseorang menghabiskan air dalam setahun. Berdasarkan data yang diproleh dari Badan Pusat Satisik, penggunaan lahan untuk kegiatan konsumsi air oleh individu standarnya adalah 0,0019 gHa/gallon. Sedangkan berdasarkan hasil penelitian, rata-rata Water Footprint siswa berkepribadian ekstrovert sebesar 0,00502 gHa/gallon (Lampiran 16). Siswa berkepribadian introvert menghabiskan 0,00637 gHa/gallon (Lampiran 17). Kegiatan konsumsi yang melebihi batas ketersediaan sumber daya alam akan membuat kota yang ditempati tentu tidak bisa menopang segala aktivitas masyarakat urban. Oleh karena itu konsep Water Footprint ini sangat tepat diterapkan dalam mengidentifikasi segala aktivitas konsumsi masyarakat Jakarta khususnya siswa di sekolah dan di rumah, mengingat pulau Jawa menjadi pulau dengan wilayah yang paling kekurangan air bersih di Indonesia. Kota Jakarta juga semakin dipenuhi oleh bangunan yang mengurangi wilayah resapan air. Bangunan yang menutupi wilayah resapan air tersebut tentu akan mengurangi ketersediaan air bagi masyarakat. Analisis Water Footprint di tingkat sekolah dan di rumah sangat berguna untuk memberikan pesan sustainabilitas kepada tiap individu siswanya. Terutama karena penggunaan pendekatan Component Method dalam menganalisis aktivitas konsumsi sumber daya alam. Pendekatan ini dapat mengidentifikasi kontribusi atau dampak dari tiap aktivitas yang spesifik terhadap lingkungan.

\section{UCAPAN TERIMA KASIH}

Penelitian mengenai pengaruh kepribadian (ekstrovert vs introvert) terhadap Water Footprint siswa sekolah menengah atas dapat terselesaikan berkat bantuan banyak pihak. Penulis mengucap banyak terimakasih terutama pada beasiswa Bidik Misi yang selama ini menanungi penulis selama empat tahun berkuliah dan dapat meyelsaikan tugas akhir strata 1 ini.

\section{DAFTAR PUSTAKA}

Barrett, John, Vallack, Harry, Jones, Andrew, \& Haq, Gary.(2002). A Material Flow 
Analysis and Ecological Footprint of York:Technical Report. Stockholm: Stockholm Environment Institute.

Baartlett, James e.,Kotrlik, Joe W. \& Chadwick, C. Hinggins.(2001). Organizatinal Research: Determining Apporopriate Sample Size in Survey Research Appropriate Sample Sive in Survey Research. Information Technology,Learning, and Performance

Journal 19 (1), 43

Bertelli, Mia \& Roark, Ellie. (2011). Marlboro College's Ecological Footprint Calculator Manual. Marlboro: Marlboro College

Bulsink, F., Hoekstra A.Y.\& Booij, M. J.(2010). The Water Footprint of Indonesian Provinces Related to the Consumption of Crop Products. Hydrology Earth System Science, 14, 119-128.

Doughty, Mark R.C. \& Hammond, Geoffrey P.(2004). Sustainability and the Built Environment at and Beyond the City Scale. Building and Environment 39 (10), 1223-1233.

Ernawi, Imam S.(2010). Ecological Footprint of Indonesia. Jakarta: Ministry of Public Work.

Gottlieb, Dan Gadot, E.Vigodaa., Haim, Abraham., \& Kissinger, M.(2011). The Ecological Footprint as an Educational tool for Sustainability: A case study analysis in an Israeli public High School. International Journal of Educational Development. Doi:10.1016/j.ijedudev.2011.03.007

Gottlieb, Dan Gadot, E.Vigodaa., Haim, Abraham., \& Kissinger, M. (2012). Analyzing The Ecological Footprint As the Instutitutional Scale-Rhe Case Of an Israeli High School. Ecological Indicators, 18.

Hubacek, K., Guan, D. \& Barua, A.(2007). Changing lifestyles and consumption patterns in developing countries: A Scenario Analysis for China and India, Futures, 39 (9), 10841096.

Kissinger, Meidad \& Haim, Abraham.(2008). Urban Hiterlands: the case of an Israeli town Ecological Footprint. Environment Development and Sustainability. 10 (4), 391-405

Mcdonald, John H.(2009). Handbook Of Biological Statistics: $2^{\text {nd }}$ Edition. Maryland: Sparky House Publishing

Merkel, Jim.(2003). Radical Simplicity: Small Footprints on A Finite Earth. Gabriola Island: New Society Publisher.

Perreau, Fanny.(2013). The Forces That Drive Consumer Behavior. theconsumerfactor.com Rees, William.(1992). Ecological Footprint and appropriated carrying capacity: What Urban Economics Levels Out. Environment and Urbanizations. 4 (2), 121-130

Simmons, Craig, Lewis, Kevin, \& Barrett, John.(2000). Two feet--- two approaches: a component based model of Ecological Footprinting. Ecological Economics. 32 (3), 375380.

Souls, Jacobus Abram.(2005). The Changing Role Of The Secondary School Principal In Building Sustanable Comunities. Education Management: University Of South Africa.

Wackernagel, Mathis \& Rees, William E.(1996). Our Ecological Footprint: Reducing Human Impact on the Earth. New Society Publisher: Gabriola Island

Wackernagel, Mathis.(1994). Ecological Footprint and Appropriated Carrying Capacity: A tool For Planning Toward Sustainability. University of British Columbia 